\title{
DIRECT AND INDIRECT ASSESSMENT OF SELENIUM STATUS IN CATTLE - A COMPARISON
}

\author{
L. PAVLATA, A. PECHOVÁ, J. ILLEK
}

Clinic of Diseases of Ruminants, Faculty of Veterinary Medicine, University of Veterinary and Pharmaceutical Sciences, Brno, Czech Republic

\author{
Received May 25, 2000
}

Accepted November 22, 2000

\begin{abstract}
Pavlata L., A. Pechová, J. Illek: Direct and Indirect Assessment of Selenium Status in Cattle - a Comparison. Acta vet. Brno 2000, 69: 281-287.

Selenium concentration and activity of glutathione peroxidase (GSH-Px) as direct and indirect indicators of selenium status were determined in whole blood samples collected from 326 cattle in 30 herds kept in various regions of the Czech Republic. The GSH-Px activity in the samples was measured by the UV method, using the set supplied by Randox. Selenium in the sample was measured using the hydride technique AAS. The two variables showed a close and significant correlation $(\mathrm{r}=0.90 ; p<0.01)$. The regression line, defined by the equation $y=6.44 x+21.4$, allowed us to determine the GSH-Px activity of $665.4 \mu \mathrm{kat} \cdot \mathrm{l}^{-1}$ as equivalent to selenium concentration in whole blood $100 \mu \mathrm{g} \cdot \mathrm{l}^{-1}$. Mean selenium concentration and mean GSH-Px activity found in whole blood samples were $78.25 \pm 46.67 \mu \mathrm{g} \cdot \mathrm{l}^{-1}$ and $525.51 \pm 335.56 \mu \mathrm{kat} \cdot 1^{-1}$, respectively. Insufficient or marginal supply of selenium was diagnosed in $64 \%$ of the animals in terms of selenium concentration, in $63 \%$ of the animals in terms of GSH-Px activity and in $55 \%$ of the animals with selenium concentrations $<100 \mu \mathrm{g} \cdot \mathrm{l}^{-1}$ and GSH-Px activity $<665.4 \mu \mathrm{kat} \cdot \mathrm{l}^{-1}$. In this study, close dependence of GSH-Px activity and selenium concentration in the blood of cattle was found. Activity values of GSH-Px were determined for the use in diagnosis of insufficient selenium in cattle in the Czech Republic.

Glutathione peroxidase, whole blood, AAS, correlation, diagnostics
\end{abstract}

Selenium had been the subject of only toxicological studies in animals and humans until Schwartz and Foltz (1957) pointed out its physiological role. Currently, many biological functions of this element present in various selenoproteins have been described. In eukaryotic organisms, selenocysteine has been identified as a component of glutathione peroxidase, tetraiodothyronine 5'-deiodase, protein $\mathrm{P}$, selenoprotein $\mathrm{W}$, and selenoprotein isolated from murine sperm mitochondriae (Fuchs 1996). Their biological functions in various animal species are the subject of continuing research.

Selenium deficiency in various animal species is manifested by both nonspecific and specific clinical signs. Their severity depends on the degree of deficiency and exertion the animal is exposed to. Well-known animal diseases due to selenium deficiency include nutritional myodystrophy of ruminants, hepatic necrosis of rats, pancreatic degeneration, reproductive failures, encephalomalacia of chicks, and others (Shamberger 1983). Since such diseases become clinically apparent only in animals suffering from a serious selenium deficiency, development of exact and practical methods for the diagnosis of subclinical metabolic disorders or insufficient selenium supply is desirable. In addition to clinical signs and microscopic lesions in muscular tissue, low selenium status can be diagnosed by increased ativities of selected enzymes of muscle cells (aspartate aminotransferase, lactate dehydrogenase and, foremost, creatine kinase). More exact methods include direct determination of selenium in blood and tissues and indirect assessment of selenium status by measurement of activity of

Address for correspondence:

MVDr. Leoš Pavlata

Clinic of Diseases of Ruminants, Faculty of Veterinary Medicine

University of Veterinary and Pharmaceutical Sciences Brno

Phone: +420541562407

Fax: +42748841

http://www vfu.cz/acta-vet/actavet.htm 
glutathione peroxidase in whole blood. Hepatic, renal and muscular tissues are most frequently used for the determination of selenium concentration. Measurement of glutahione peroxidase activity is usually preferred for diagnostic purposes as a less exacting and less expensive method. The assessment of selenium status by measurement of GSH-Px activity is based on the knowledge of its biological functions. GSH-Px is involved particularly in the antioxidant system of the organism. Its role consists in degradation of hydrogen peroxide to organic hydroperoxides in most mammalian cells. Such function in the protection of erythrocytic haemoglobin was described by Mills as early as in 1957, but selenium was identified as a component of this enzyme only 16 years later (Rotruck et al. 1973). The presence of GSH-Px in cytosol and of vitamin E in cell membranes protects cells against oxidative damage (S mith et al. 1988). It has been established that $98 \%$ of the activity of GSH-Px is bound to erythrocytes (Scholtz and Hutchins on 1979). Since GSH-Px becomes a component of erythrocytes already at the stage of erythropoiesis, its activity in whole blood indicates the long-term selenium status, while blood plasma selenium concentration reflects rather the acute status (Gerlof 1992). The objective of our study was to assess the correlation between the activity of GSH-Px and selenium concentration in whole blood, to calculate by regression analysis the activity of GSH-Px corresponding to the selenium concentration $100 \mathrm{~g} \cdot \mathrm{l}^{-1}$ of whole blood regarded as the reference value for cattle, to evaluate the measurement of GSH-Px as a method for the determination of selenium status or diagnosis of selenium deficiency in the conditions prevailing in the Czech Republic, and to compare the results of chemical and biochemical analyses for the assessment of selenium status in the set of experimental cattle.

\section{Materials and Methods}

Blood samples were collected from 326 cattle (278 dairy cows, 29 bulls, 19 heifers) on 30 farms in various parts of the Czech Republic (northern and northeastern Bohemia, southern and northern Moravia). The farms were selected to represent herds differing in selenium supply (animals fed nonsupplemented feed vs. animals receiving a selenium-containing mineral supplement) to obtain the widest possible range of low and sufficient blood selenium concentrations and the corresponding GSH-Px activities. No animals that had been treated parenterally with selenium during the past eight weeks, or animals from farms in which selenium supplementation was newly introduced, were included into the investigations. The samples were collected by puncture of v. jugularis into heparinised disposable test tubes.

The GSH-Px activity in the samples was measured by the method developed by Paglia and Valentine (1967), using the set supplied by Randox and the automatic analyser COBAS MIRA, and expressed in terms of $\mu \mathrm{kat} \cdot 1^{-1}$ of whole blood.

Selenium concentration was determined in the same whole blood sample. Prior to analysis, the samples were mineralised in a closed system of microwave digestion in the presence of nitric acid and hydrogen peroxide using the Milestone Model MLS 1200 apparatus. After removal of nitric acid from the digested sample in the evaporation rotor of the same apparatus, the water solution was mixed with $20 \%$ hydrochloric acid. Selenium in the processed sample was measured using the hydride technique AAS and the UNICAM 939 spectrometer. Selenium concentration was expressed in terms of $\mu \mathrm{g} \cdot \mathrm{l}^{-1}$ of whole blood.

The relation between results of the two methods was tested by calculation of correlation coefficient (r) using the EXCEL and STAT Plus software, regression analysis and calculation of regression line equation allowing the determination of presumed values of $y$ (GSH-Px) for various values $x$ (selenium). Selenium status of the sampled animals was assessed using the direct and the indirect method of selenium determination.

\section{Results and Discussion}

Basic statistical characteristics of the obtained data are given in Table 1 and the relation between selenium concentration and GSH-Px activity in whole blood in Fig. 1 completed with a trend-connecting line.

A highly significant correlation $(r=0.90 ; p<0.01)$ was found between results of the two methods. 


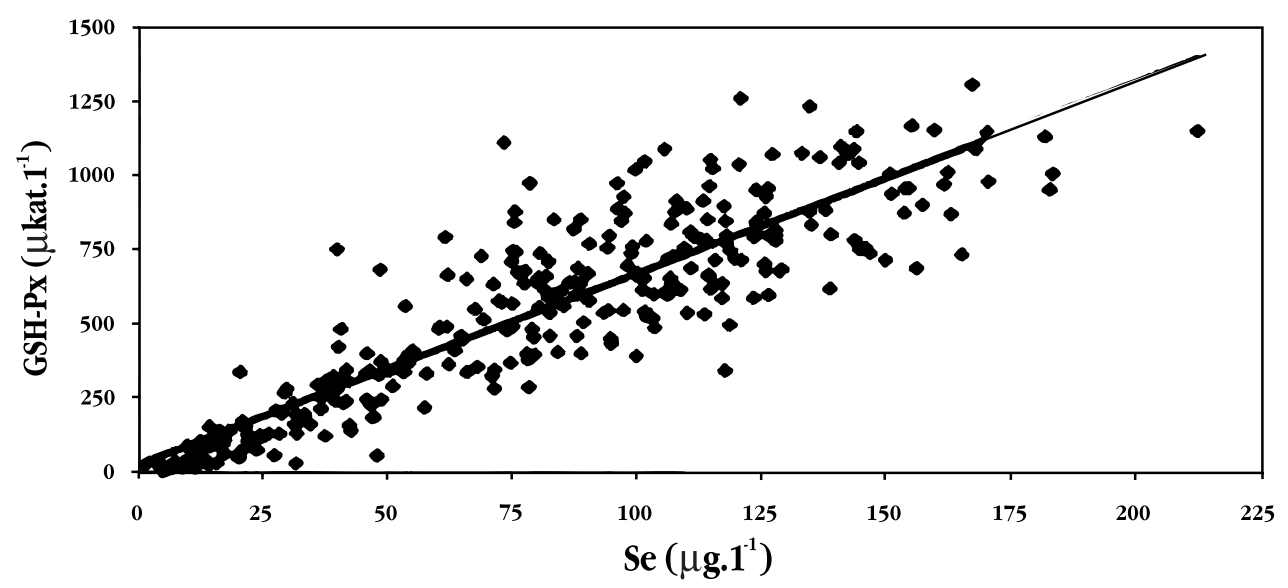

Figure 1. Relation between selenium concentration and GSH-Px activity in bovine whole blood

Table 1

Selenium concentrations and GSH-Px activities in bovine whole blood $(n=326)$

\begin{tabular}{|l|c|c|}
\hline Parameter & Selenium $\left(\mathrm{g} \cdot \mathrm{l}^{-1}\right)$ & GSH-Px $\left(\mu \mathrm{kat} \cdot \mathrm{l}^{-1}\right)$ \\
\hline mean & 78.25 & 525.51 \\
\hline S.D. & 46.67 & 335.56 \\
\hline variation coefficient $(\%)$ & 59.64 & 63.85 \\
\hline min. & 1.33 & 0.41 \\
\hline max. & 212.40 & 1521.1 \\
\hline
\end{tabular}

Regression analysis yielded the following function:

$y=6.44 x+21.40$ with confidence interval $(95 \%)$

$y_{(\min )}=6,44-10,4$

$y_{(\max )}=6,44+53,2$

Statistical significance of linear regresion was evaluated by analysis of variance (critical value $\mathrm{F}(0.01)=7.88$; calculated value $\mathrm{F}=1334.24)$.

Substitution of the most frequently published reference values of selenium concentration in whole blood (70 to $100 \mu \mathrm{g} \cdot \mathrm{l}^{-1}$ ) for $x$ results in GSH-Px activities ranging from 472.20 to $665.40 \mu \mathrm{kat} \cdot 1^{-1}$.

The highly significant correlation between selenium concentration and GSH-Px activity in whole blood found in our investigations is consistent with data published by other authors. Thus Thompson et al. (1981) obtained the correlation coefficient $r=0.97$, Koller et al. (1984) $r=0.87$, Erskine et al. (1987) $r=0.93$, Khan et al. (1987) $r=0.92$, and Mass et al. (1993) $r=0.97$. Zamorski et al. (1995), who investigated the relation between selenium concentration and GSH-Px activity in various species, found significant correlations for cattle $(r=0.63)$, sheep $(r=0.92)$, swine $(r=1.0)$, horses $(r=0.81)$, and humans $(r=0.88)$. It can therefore be concluded that our findings confirmed the close correlation between selenium concentration and GSH-Px activity in whole blood. The enzymatic method is without doubt more convenient for veterinary diagnostics in that it is much simpler and less expensive. Blood samples can be stored at room temperature for up 
to 10 days without any demonstrable changes in the activity of the enzyme. No demonstrable differences were found in the results expressed in $\mu \mathrm{kat} \cdot \mathrm{l}^{-1}$ and IU.g. $\mathrm{g}^{-1}$ haemoglobin (Pavlata et al. 1997). Expression in $\mu \mathrm{kat} \cdot \mathrm{l}^{-1}$ was preferred in this study, because the analysis for haemoglobin concentration could be omitted. A certain problem in the interpretation of GSH-Px values results from differences in reference values given by various authors. Arthur et al. (1979) considers the selenium concentration of $96 \mu \mathrm{g} \cdot \mathrm{l}^{-}$ 1 corresponding to GSH-Px activity of $14360 \mathrm{IU} \cdot \mathrm{l}^{-1}$, or approx. $240 \mu \mathrm{kat} \cdot \mathrm{l}^{-1}$ whereas the values given by Tasker et al. (1987) are $75.90 \mu \mathrm{g} \cdot \mathrm{l}^{-1}$ and $300 \mu \mathrm{kat} \cdot \mathrm{l}^{-1}$. Ortman and Pehrson (1999), who studied effects of various forms of selenium supplementation in dairy cows, reported erythrocytic GSH-Px activity 1400 to $1600 \mu \mathrm{kat} \cdot \mathrm{l}^{-1}$ for cows with blood selenium concentrations around $90 \mu \mathrm{g} \cdot \mathrm{l}^{-1}$. The corresponding values given by Pehrson et al. (1999) were $1869 \pm 230 \mu \mathrm{kat} \cdot \mathrm{l}^{-1}$ and $112 \pm 11 \mu \mathrm{g} \cdot \mathrm{l}^{-1}$. Assessment of selenium status in terms GSH-Px activity is convenient foremost for the diagnosis of deficiency or insufficient supply of selenium. It is not suitable for the demonstration of excessive selenium intake, because increasing concentration of blood selenium is paralleled by an increase in GSH-Px activity only to a certain limit and remains a plateau thereafter. No such phenomenon was observed in our investigations, because the selenium concentrations were generally low. The highest selenium concentration recorded in our comparative experiments was $212 \mu \mathrm{g} \cdot \mathrm{l}^{-1}$ which is not indicative of excessive supply.

Selenium status in the sampled animals was assessed using the following scoring scheme suggested by V an Saun (1990): selenium deficiency at $<40 \mu \mathrm{g} \cdot \mathrm{l}^{-1}$; marginal status at 50 to $90 \mu \mathrm{g} \cdot \mathrm{l}^{-1}$; adequate supply at $100 \mu \mathrm{g} \cdot \mathrm{l}^{-1}$. A similar scheme was suggested also by Grunder and Auer (1995), who interpreted selenium concentrations $<40 \mu \mathrm{g} \cdot \mathrm{l}^{-1}$ as indicative of deficiency, those between 40 and $70 \mu \mathrm{g} \cdot \mathrm{l}^{-1}$ as marginal, and those $70 \mu \mathrm{g} \cdot \mathrm{l}^{-1}$ as adequate. Scholz and Fleischer (1996) developed a more detailed six-grade scheme distinguishing among extreme deficiency $\left(10 \mu \mathrm{g} \cdot \mathrm{l}^{-1}\right)$, serious deficiency $\left(10\right.$ to $\left.30 \mu \mathrm{g} \cdot \mathrm{l}^{-1}\right)$, medium deficiency (30 to $50 \mu \mathrm{g} \cdot \mathrm{l}^{-1}$ ), moderate deficiency (50 to $70 \mu \mathrm{g} \cdot \mathrm{l}^{-1}$ ), sufficient supply (70 to $\left.90 \mu \mathrm{g} \cdot 1^{-1}\right)$, and abundant supply $\left(100 \mu \mathrm{g} \cdot 1^{-1}\right)$. The results obtained in our studies are shown in Tables 2 and 3.

Table 2

Assessment of selenium status in terms of Se concentrations in whole blood

\begin{tabular}{|c|c|c|c|}
\hline Se concentration $\left(\mu \mathrm{g} \cdot \mathrm{P}^{-1}\right)$ & Number of animals & Percentage & Cumulated percentage \\
\hline$<40$ & 89 & 27 & \\
\hline 40 to 70 & 48 & 15 & 64 \\
\hline 70 to 100 & 73 & 22 & 36 \\
\hline$>100$ & 116 & 36 & \\
\hline
\end{tabular}

The data show that selenium concentrations in whole blood were insufficient or marginal in $64 \%$ of the tested animals.

Table 3

Selenium deficiency in terms of GSH-Px activity and selenium concentration in whole blood

\begin{tabular}{|l|c|c|}
\hline Animals & GSH-Px $<665.40 \mu \mathrm{kat} \cdot \mathrm{l}^{-1}$ & $\begin{array}{c}\mathrm{Se}<100 \mu \mathrm{g} \cdot \mathrm{l}^{-1}, \\
\text { GSH-Px }<665.40 \mu \mathrm{kat} \cdot \mathrm{l}^{-1}\end{array}$ \\
\hline Number & 204 & 180 \\
Percentage & 63 & 55 \\
\hline
\end{tabular}

The results of examination of animals of the individual herds are shown in Table 4. 
Table 4

Selenium concentrations $\left(\mu \mathrm{g} \cdot \mathrm{l}^{-1}\right)$ and GSH-Px activities $\left(\mu \mathrm{kat} \cdot \mathrm{l}^{-1}\right)$ in whole blood of animals $(\mathrm{D}=$ dairy cows; $\mathrm{B}=$ bulls; $\mathrm{H}=$ heifers $)$ of the individual herds; means $=\mathrm{S}$. $\mathrm{D}$. and correlation coefficients ( $\mathrm{r}$ ) and significance $(* p<0.05, * * p<0.01)$ are given

\begin{tabular}{|c|c|c|c|c|c|c|}
\hline Herd & $\begin{array}{l}\text { Characteristics } \\
\text { of animals }\end{array}$ & $\begin{array}{l}\text { Number } \\
\text { of animals }\end{array}$ & $\begin{array}{c}\text { Selenium } \\
\text { concentrations }\left(\mu \mathrm{g} \cdot 1^{-1}\right)\end{array}$ & $\begin{array}{l}\text { GSH-Px activities } \\
\qquad\left(\mu \mathrm{kat} \cdot \mathrm{l}^{-1}\right)\end{array}$ & $\mathrm{r}$ & $p$ \\
\hline & & & Mean \pm S.D. & Mean \pm S.D. & & \\
\hline 1 & B & 7 & $8.40 \pm 1.44$ & $20.91 \pm 4.29$ & 0.56 & - \\
\hline 2 & B & 10 & $37.60 \pm 29.36$ & $218.86 \pm 219.53$ & 0.93 & ** \\
\hline 3 & B & 8 & $38.41 \pm 7.94$ & $300.56 \pm 61.58$ & 0.79 & $*$ \\
\hline 4 & B & 4 & $51.18 \pm 41.99$ & $434.42 \pm 443.01$ & 0.91 & $* *$ \\
\hline 5 & $\mathrm{H}$ & 4 & $40.50 \pm 3.78$ & $302.27 \pm 70.47$ & 0.75 & - \\
\hline 6 & $\mathrm{H}$ & 10 & $45.33 \pm 8.22$ & $325.91 \pm 70.47$ & 0.66 & $*$ \\
\hline 7 & $\mathrm{H}$ & 5 & $74.29 \pm 14.75$ & $471.05 \pm 191.93$ & 0.14 & - \\
\hline 8 & $\mathrm{D}$ & 9 & $9.41 \pm 9.08$ & $22.32 \pm 6.54$ & 0.30 & - \\
\hline 9 & $\mathrm{D}$ & 14 & $14.29 \pm 4.03$ & $85.4 \pm 48.33$ & 0.81 & $* *$ \\
\hline 10 & $\mathrm{D}$ & 14 & $28.29 \pm 6.90$ & $171.97 \pm 68.73$ & 0.86 & $* *$ \\
\hline 11 & $\mathrm{D}$ & 24 & $29.40 \pm 12.02$ & $140.32 \pm 74.42$ & 0.72 & ** \\
\hline 12 & $\mathrm{D}$ & 17 & $62.92 \pm 28.23$ & $405.64 \pm 196.02$ & 0.80 & ** \\
\hline 13 & D & 5 & $64.29 \pm 45.98$ & $561.04 \pm 393.06$ & 0.97 & ** \\
\hline 14 & $\mathrm{D}$ & 7 & $72.43 \pm 10.73$ & $355.60 \pm 79.15$ & 0.59 & - \\
\hline 15 & $\mathrm{D}$ & 10 & $74.24 \pm 14.75$ & $471.05 \pm 191.93$ & 0.67 & $*$ \\
\hline 16 & $\mathrm{D}$ & 12 & $77.68 \pm 34.33$ & $676.76 \pm 234.78$ & 0.74 & ** \\
\hline 17 & $\mathrm{D}$ & 15 & $87.96 \pm 12.17$ & $767.57 \pm 164.78$ & 0.61 & $*$ \\
\hline 18 & $\mathrm{D}$ & 8 & $88.84 \pm 14.57$ & $597.10 \pm 42.11$ & -0.08 & - \\
\hline 19 & $\mathrm{D}$ & 17 & $92.10 \pm 17.52$ & $564.72 \pm 113.20$ & 0.67 & ** \\
\hline 20 & $\mathrm{D}$ & 15 & $94.28 \pm 29.6$ & $653.35 \pm 215.14$ & 0.85 & ** \\
\hline 21 & $\mathrm{D}$ & 8 & $98.98 \pm 32.18$ & $691.68 \pm 186.40$ & 0.62 & - \\
\hline 22 & $\mathrm{D}$ & 6 & $100.09 \pm 35.11$ & $541.75 \pm 290.70$ & 0.98 & $* *$ \\
\hline 23 & $\mathrm{D}$ & 11 & $101.99 \pm 14.00$ & $750.93 \pm 188.56$ & 0.35 & - \\
\hline 24 & $\mathrm{D}$ & 9 & $119.12 \pm 14.64$ & $710.56 \pm 59.20$ & 0.17 & - \\
\hline 25 & $\mathrm{D}$ & 11 & $120.11 \pm 20.82$ & $672.36 \pm 95.57$ & 0.29 & - \\
\hline 26 & $\mathrm{D}$ & 14 & $121.51 \pm 25.32$ & $663.09 \pm 142.74$ & 0.63 & $*$ \\
\hline 27 & $\mathrm{D}$ & 16 & $132.85 \pm 27.88$ & $965.90 \pm 134.88$ & 0.43 & - \\
\hline 28 & $\mathrm{D}$ & 12 & $138.73 \pm 20.35$ & $890.17 \pm 224.77$ & 0.59 & $*$ \\
\hline 29 & $\mathrm{D}$ & 8 & $147.99 \pm 21.88$ & $1168.56 \pm 184.31$ & 0.48 & - \\
\hline 30 & $\mathrm{D}$ & 10 & $158.92 \pm 30.28$ & $970.47 \pm 116.01$ & 0.79 & $* *$ \\
\hline
\end{tabular}


The data show a high percentage of selenium-deficient animals in local cattle herds. Under such conditions of low intake, both the direct and the indirect method can be used for the assessment of selenium status, because the concentrations are too low for GSH-Px activity to reach the plateau. The discrepancy of not more than $9 \%$ of animals showing different results by either of the methods and a combination of both is irrelevant to clinical practice. Our results indicate that sufficient selenium supply can be assumed in animals with GSH-Px activity in whole blood higher than $600 \mu \mathrm{kat} \cdot \mathrm{l}^{-1}$. Selenium concentrations lower than $70 \mu \mathrm{g} \cdot \mathrm{l}^{-1}$ were found in only 5 animals showing GSH-Px higher than $600 \mu \mathrm{kat} \cdot \mathrm{l}^{-1}$. On the other hand, GSH-Px was lower than $600 \mu \mathrm{kat} \cdot \mathrm{l}^{-1}$ in 13 animals with selenium higher than $100 \mu \mathrm{g} \cdot \mathrm{l}^{-1}$. Hence, an interpretation error is more probable in animals with a higher selenium status than indicated by GSH-Px activity. Even this error can be minimised by observation of the recommendation that tests for trace element deficiencies should be carried out rather in groups of animals representing all age categories of a herd than in individual animals. The results shown in Table 4 indicate considerable among-herd differences in the selenium status which reflect above all differences in selenium supply in the rations. Whole blood selenium concentrations exceeding $100 \mu \mathrm{g} \cdot 1^{-1}$ were found in most of the animals fed seleniumsupplemented rations. On the other hand, no selenium-supplemented rations were fed in the herds No. 1, 8, 9, 10 and 11. Therefore, it can be concluded that the natural amount of selenium in rations fed to cattle in the Czech Republic is mostly insufficient. The results also indicate a higher tendency towards selenium deficiency in bulls and heifers, which invariably showed low selenium concentrations. Owing to large within-area differences among the individual herds, no conclusions as to increased occurrence of selenium deficiency in a specific region of the Czech Republic can be drawn. The close relationship between selenium concentrations and activities of GSH-Px is documented by the high correlation coefficients. However, even in the cases where the correlation was nonsignificant due to a low number of animals tested, the determination of GSH-Px activity allowed us to assess the selenium state.

\section{Zásobení organismu selenem u skotu - porovnání přímého a nepřímého stanovení}

V rámci naší studie byla odebrána krev od 326 kusů skotu z 30 různých chovů České republiky a provedeno stanovení koncentrace selenu a aktivity glutationperoxidázy (GSH-Px) v plné krvi jako přímá a nepřímá metoda určení stupně zásobení organismu selenem. Aktivita GSH-Px byla stanovena UV metodou s použitím setu Randox a selen hydridovou technikou AAS. Mezi oběma proměnnými byl korelační analýzou zjištěn těsný, statisticky významný vztah $(\mathrm{r}=0,90 ; p<0,01)$ a regresní analýzou vypočtena rovnice regresní př́mky $(\mathrm{y}=6,44 \mathrm{x}+21,4)$. Na jejím základě byla stanovena aktivita GSH-Px 665,4 $\mu \mathrm{kat} \cdot \mathrm{l}^{-1}$ jako hodnota odpovídající koncentraci selenu v plné krvi $100 \mu \mathrm{g} \cdot \mathrm{l}^{-1}$. Při zjištěných průměrných hodnotách koncentrace selenu a GSH-Px v plné krvi 78,25 $\pm 46,67 \mu \mathrm{g} \cdot \mathrm{l}^{-1}$, resp. $525,51 \pm 335,56 \mu \mathrm{kat} \cdot \mathrm{l}^{-1}$ bylo $64 \%$ zvírat vyhodnoceno jako nedostatečně nebo marginálně zásobených selenem dle koncentrace selenu v krvi, $63 \%$ podle aktivity GSH-Px a 55\% při kombinaci obou metod, tj. s hodnotami koncentrace Se $\mathrm{v}$ krvi $<100 \mu \mathrm{g} \cdot \mathrm{l}^{-1}$ a aktivitou GSH-Px $<665,4 \mu \mathrm{kat} \cdot \mathrm{l}^{-1}$. Lze tedy konstatovat, že byla prokázána vysoká závislost aktivity GSH-Px a koncentrace selenu v plné krvi skotu a stanoveny prŕíslušné hodnoty aktivity GSH-Px pro účely diagnostiky karence selenu u skotu v České republice.

Acknowledgement

The work was supported by the Ministry of Education, Youth, and Sports of the Czech Republic (grant No. 161700002/1999). 


\section{References}

ARTHUR, J. R., PRICE, J., MILLS, C. F. 1979: Observations on the selenium status of cattle in the north-east of Scotland. Vet. Rec. 104: 340-341

ERSKINE, R. J., EBERHART, R. J., HUTCHINSON, L. J., SCHOLZ, R. W. 1987: Blood selenium concentrations and glutathione peroxidase activities in dairy herds with high and low somatic cell counts. J. Am. Vet. Med. Ass. 190: $1417-1421$

FUCHS, O. 1996: Selenoproteiny. Chem. Listy 90: 444- 450

GERLOF, B. J. 1992: Effect of selenium supplementation on dairy cattle. J. Anim. Sci. 70: 3934-3940

GRUNDER, H. D., AUER, S. 1995: Selenversorgung in hessischen Rinderbeständen und Möglichkeiten der Prophylaxe. Tierärzt. Umsch. 50: 250-255

KHAN, A. A., LOVEJOY, D., SHARMA, A. K., SHARMA, R. M., PRIOR, M. G., LILLIE, L. E. 1987: Effects of high dietary sulphur on enzyme activities, selenium concentrations and body weights of cattle. Can. J. Vet. Res. 51: 174-180

KOLLER, L. D., SOUTH, P. J., EXON, J. H., WHITBECK, G. A., MAAS, J. 1984: Comparisons of selenium levels and blood glutathione peroxidase activity in bovine whole blood. Can. J. Comp. Med. 48: 431-433

MILLS, G. C. 1957: Hemoglobin catabolism I. Glutathione peroxidase, an erytrocyte enzyme which protects hemoglobin from oxidative breakdown. J. Biol. Chem. 229: 189-19

MAAS, J., PEAUROI, J. R., TONJES, T., KARLONAS, J., GALEY, F. D., HAN, B. 1993: Intramuscular selenium administration in selenium-deficient cattle. J. Vet. Int. Med. 7: 342-348

ORTMAN, K., PEHRSON, B. 1999: Effect of selenate as a feed supplement to dairy cows in comparison to selenite and selenium yeast. J. Anim. Sci. 77: 3365-3370

PAGLIA, D. E., VALENTINE, W. N. 1967: Studies on the quantitative and qualitative characterisation of erythrocyte glutathione peroxidase. J. Lab. Clin. Med. 70: 158-169

PAVLATA, L., PECHOVÁ, A., SEDLÁKOVÁ, D. 1997: Laboratorní diagnostika karence selenu u skotu. Project Report, VFU Brno, 9 p.

PEHRSON, B., ORTMAN, K., MADJID, N., TRAFIKOWSKA, U. 1999: The influence of dietary selenium as selenium yeast or sodium selenite on the concentration of selenium in the milk of suckler cows and on the selenium status of their calves. J. Anim. Sci. 77: 3371-3376

ROTRUCK, J. T., POPE, A. L., GANTHER, H. E., SWANSON, A.B., HAFEMAN, D.G., HOEKSTRA, W. G. 1973: Selenium: biochemical role as a component of glutathione peroxidase. Science 179: $588-590$

SCHOLTZ, R. V., HUTCHINSON, L. J. 1979: Distribution of glutathione peroxidase activity and selenium in the blood of dairy cows. Am. J. Vet. Res. 40: 245-249

SCHOLZ, H., FLEISCHER, P. 1996: Zdravotní poruchy skotu způsobené nedostatkem selenu. In: Veterinární péče $\mathrm{v}$ chovech skotu - dodatek, Forum veterinarium Brno, 1-4

SCHWARZ, K., FOLTZ, C. M. 1957: Selenium as an integral part of factor 3 against dietary necrotic liver degeneration. J. Am. Chem. Soc. 79: 3292-3293

SHAMBERGER, R. J. 1983: Biochemistry of Selenium. Plenum Press, New York, 334 p.

SMITH, K. L., HOGAN, J. S., CONRAD, H. R. 1988: Selenium in dairy cattle: its role in disease resistance. Vet. Med. Small. Anim. Pract., 83 1: 72-78

TASKER, J. B., BEWICK, T. D., CLARK, R. G., FRASER, A. J. 1987: Selenium response in dairy cattle. N. Z. Vet. J. 35: 139-140

THOMPSON, K. G., FRASER, A. J., HARROP, B. M., KIRK, J. A., BULLIANS, J., CORDES, D. O. 1981: Glutathione peroxidase activity and selenium concentration in bovine blood and liver as indicators of dietary selenium intake. N. Z. Vet. J. 29: 3-6

VAN SAUN, R. J. 1990: Rational approach to selenium supplementation essential. Feedstuffs (Jan 15), 15-17

ZAMORSKI, R., BOROWSKA, K., KOPER, J. 1995: Selenium, zinc and magnesium content, and glutathione peroxidase activity in blood of humans and some animal species. In: 15. Arbeitstagung Mengen- und Spurenelemente, Jena, 421-427 